\title{
Fighting for Credibility: US Reputation Building in Asymmetric Conflicts from the Gulf War to Syria (1991-2013)
}

\author{
Frank P. HaRvey Dalhousie University \\ John MitTon Dalhousie University
}

Is fighting for credibility prudent? Does a failure to follow through on a coercive diplomatic or military threat undermine a leader's credibility? Can leaders or states acquire reputations from adversaries for being resolute or irresolute? How do these reputations emerge or change and are they transferable from one context (administration, opponent, time frame, issue area, region or crisis) to another? This paper revisits the theory and policy debates that resurfaced during the crisis over Syria's chemical weapons (CW) use in late summer 2013, placing these central disputes within the broader context of US asymmetric crises over the last several decades and ongoing divisions among scholars regarding the relevance of reputation in international politics. ${ }^{1}$ While definitive answers to the above questions remain elusive, the evidence in this paper suggests that reputations do matter, can form and occasionally transfer both within and across crises. These findings directly challenge the so-called "emerging consensus" that reputations do not matter, cannot form, and never transfer-a position that figured prominently in debates over the American response to the Syria CW crisis.

The authors would like to thank three anonymous reviewers for their helpful and insightful comments as well as the editorial staff at CJPS for excellent editorial assistance. Frank Harvey wishes to acknowledge SSHRC (grant \#435-2014-1529) for generous financial support. John Mitton also wishes to acknowledge SSHRC (grant \#752-2015-1381) as well as the Killam Trusts for their financial support.

Frank P. Harvey and John Mitton, Department of Political Science, Dalhousie University, 6299 South St, Rm 301, PO Box 15000, Halifax, NS, Canada, B3H 4R2, Email: frank.harvey@dal.ca and john.mitton@dal.ca 
The paper proceeds as follows. First, we offer a brief overview of the debates about reputation and credibility that resurfaced during the Syria chemical weapons crisis in 2013. Second, we directly challenge the theories, arguments and evidence put forward by those who dismiss reputations as irrelevant to international politics. Third, we outline several reasons why reputations and past actions are central to crisis decision making and, in section four support our position with additional case evidence from a series of asymmetric crises involving the US over the last several decades: Bosnia-Herzegovina (1992-1995), Kosovo (1998-1999) and Iraq (1991-2003). Fifth, we apply the lessons learned from these cases by identifying similar patterns of behaviour that confirm the role of reputations in the Syria crisis from 2012 to 2013. The paper concludes with our thoughts on the overall implications for US foreign policy, particularly in relation to the transferability of reputations for resolve, fighting for credibility and Washington's application of coercive diplomacy in this and future asymmetric conflicts.

\section{Debating Credibility in Syria 2013}

Critically important questions about the relevance of reputations framed the foreign policy debate following the sarin gas attacks by the Syrian military in August 2013. In response to the attacks, President Obama joined senior members of his national security team to repeatedly emphasize, in every press conference and congressional testimony, the linked imperatives to enforce global prohibitions on the use of chemical weapons and reinforce the credibility of the following "red-line" warning issued by the president a year earlier: ${ }^{2}$

We have communicated in no uncertain terms with every player in the region that that's a red line for us and that there would be enormous consequences if we start seeing movement on the chemical weapons front or the use of chemical weapons. That would change my calculations significantly. (Office of the Press Secretary, 2012; emphasis added)

Almost exactly one year later, on August 21, 2013, the Syrian military launched a series of sarin gas attacks against rebel strongholds throughout the Ghouta agricultural belt east of Damascus, killing 1400 Syrians (including 400 children). Bashar al-Assad's flagrant disregard of the red-line threat represented a clear case of US deterrence failure. Punitive airstrikes against the regime, Obama argued, were now essential to bolster Washington's credibility (particularly in light of repeated failures to respond to 11 previous chemical attacks by the Syrian military), provide additional military support to the insurgency, impose costs on Assad for 


\begin{abstract}
Do international reputations matter and are they transferable from one context to another? These critically important questions continue to frame policy debates surrounding US responses to crises in Syria and Ukraine. For skeptics, past actions and reputations for resolve have no bearing on an adversary's assessment of US credibility; relative "power" and "interests" explain behaviour (Hopf, 1994; Mercer, 1996; Press, 2005; Walt, 2013; Zakaria 2013). We argue that scholars who dismiss the relevance of reputations typically sidestep important questions about how adversaries actually acquire relevant information about US interests and power. Building on an extensive collection of qualitative and quantitative studies of US deterrence encounters in asymmetric conflicts over the last two decades, we argue that lessons from past actions inform an adversary's interpretation of US interests in any given case and provide crucial information about Washington's willingness to deploy military force (capabilities). By implication, lessons learned from Bosnia 1992-1995 informed actions in Kosovo 1999, which, in turn, informed subsequent assessments of US interests and commitments in Iraq 1991, 1998 and 2003. Similarly, lessons about US reputations and credibility in Iraq from 1991 to 2003 were critically important to successful WMD diplomacy in Syria. Policy implications are addressed in the conclusion.
\end{abstract}

Résumé. La réputation internationale des États est-elle importante et dans quelle mesure peut-elle être transférable d'un événement à l'autre? Ces questions, d'une importance capitale, continuent d'encadrer le débat sur la réaction des États-Unis aux crises syrienne et ukrainienne. Pour les sceptiques, les actions passées et une réputation de fermeté n'ont aucune incidence sur l'estimation de la crédibilité des États-Unis aux yeux d'un adversaire potentiel. Selon eux, la puissance et les intérêts relatifs expliquent davantage le comportement des États (Hopf, 1994; Mercer, 1996; Press 2005; Walt, 2013; Zakaria 2013). Dans cet article, nous soutenons que les chercheurs qui rejettent la pertinence de la réputation ont tendance à ignorer des questions cruciales sur la façon dont les États acquièrent l'information pertinente sur la puissance et les intérêts des États-Unis. En s'appuyant sur un vaste corpus d'études qualitatives et quantitatives sur la dissuasion américaine lors des conflits asymétriques des deux dernières décennies, notre analyse suggère que les leçons du passé influencent la façon dont les adversaires des États-Unis interprètent les intérêts américains ainsi que la volonté de Washington de déployer ses capacités militaires. Ainsi, les leçons tirées des interventions en Bosnie 1992-1995 ont éclairé les actions au Kosovo 1999, lesquelles, à leur tour, ont renseigné les évaluations des intérêts et des engagements militaires américains en Irak 1991, 1998 et 2003. De même, les interventions en Irak de 1991 à 2003 ont permis de tirer des leçons importantes sur la réputation et la crédibilité des États-Unis qui furent essentielles au succès des pourparlers diplomatiques lors de la crise des armes de destruction massive en Syrie. Nous aborderons les ramifications politiques de notre analyse dans la conclusion.

violating a widely endorsed international norm and strengthen the administration's reputation for enforcing red-lines tied to this and other deterrent threats, a message directed, in part, at officials in Iran and North Korea. ${ }^{3}$

Scores of widely cited (and re-tweeted) articles, op-eds and blog posts by prominent international relations scholars and foreign policy experts immediately challenged the strategic logic underpinning Obama's response to the Syrian attacks (see, for example, Biddle, 2013; Drezner, 2013a, 2013b; Fallows, 2013; Friedersdorf, 2013; Klein, 2013; Larison, 2013; Manzi, 2013; Slater, 2013; Walt, 2013; Zakaria, 2013). Citing an "emerging consensus" in the academic literature, connected primarily to the findings from historical case studies on reputation building in international politics 
by Daryl Press (2007), Jonathan Mercer (1996) and Ted Hopf (1994) (hereafter referred to as $\mathrm{P}-\mathrm{M}-\mathrm{H}$ ), critics dismissed as foolish the threat to strike Syria to reinforce the president's mistakenly issued red-line. ${ }^{4}$ "What is most striking about this affair," Stephen Walt argued, "is how Obama seems to have been dragged, reluctantly, into doing something that he clearly didn't want to do.... He foolishly drew a 'red line' a few months back, so now he's getting taunted with the old canard about the need to "restore US credibility" (2013). Walt joined many other foreign policy analysts to summarily reject the notion that threatening to fight for credibility in Syria made any sense. The president's strategy, they insisted, would have no bearing on impressions of Washington's resolve to protect the country's core interests in other regions, and was completely unrelated to strengthening the credibility of red-lines issued against other adversaries.

The president's critics found the $\mathrm{P}-\mathrm{M}-\mathrm{H}$ research persuasive enough to elicit very clear and consistent policy recommendations: ignore the red-line threat, halt any plans for punitive airstrikes against the Syrian regime, and reject any suggestion that backing off would damage Washington's reputation for resolve or undermine the credibility of its deterrent threats here or elsewhere. The only rational option, they argued, was to back away from the brink. Moreover, the threat of "unbelievably small" airstrikes would do nothing to reinforce US credibility or satisfy the conditions for successful coercion. Even worse, limited attacks would carry an enormous risk of escalation (mission creep) with no reasonable guarantee of resolving the underlying issues. In sum, Obama should accept the "fact" that fighting for credibility is a waste of time, acknowledge that his red-line threat was a bluff, and fold. As Jerome Slater counselled, "the United States would greatly benefit from a healthy dose of isolationism to at least partly balance what ought to be called "mindless interventionism"” (2013).

Despite these strong criticisms, dire warnings and impassioned policy recommendations, the Obama administration discarded critics' advice and continued to bolster its coercive threat, openly moved forward with operational plans to mount punitive airstrikes against the Assad regime, approached the US Congress for authorization, and buttressed the threat by extending the deployments of warships and aircraft carriers in the eastern Mediterranean (PressTV, 2013). White House officials and several senior congressional leaders from both parties used every opportunity they were given to highlight the country's (and international community's) obligation to enforce global norms against the use of chemical weapons and consistently underscored the strategic imperative to reinforce American credibility and resolve.

On September 3, 2013, the US Senate Foreign Relations Committee boosted the credibility of Washington's coercive threat by voting in favour of a draft resolution authorizing the president to "use the Armed Forces of the United States as he determines to be necessary and 
appropriate" in a limited and tailored manner against legitimate military targets in Syria, only to:

(1) respond to the use of weapons of mass destruction by the Syrian government in the conflict in Syria; (2) deter Syria's use of such weapons in order to protect the national security interests of the United States and to protect our allies and partners against the use of such weapons; and (3) degrade Syria's capacity to use such weapons in the future. ${ }^{5}$

The resolution gave the president up to 60 days to complete the initial operation, and another 30 days if required, essentially two weeks longer than the successful 78-day bombing campaign launched by US/NATO forces in 1999 against Serb targets in Kosovo and Belgrade.

When Secretary of State John Kerry suggested in a press conference that Assad could avoid the airstrikes if he turned over "every single bit of his chemical weapons to the international community in the next week... without delay and [with] full and total accounting," (quoted in Mohamed and Osborn, 2013) Russian president Vladimir Putin (Assad's key ally and backer) jumped at the offer, immediately accepted the conditions stipulated in Kerry's unscripted comments, persuaded Assad to take the deal, and initiated discussions leading to the UN disarmament resolution. Notwithstanding the many concerns expressed by critics, both Assad and Putin ultimately concluded that the probability, risks and costs of a US air campaign were simply too high and potentially damaging, regardless of the limits implicit in an "unbelievably small" strike or any other qualifying conditions attached to the draft congressional resolution.

In sum, coercive diplomacy (both deterrence and compellence) ultimately succeeded. Assad acknowledged for the first time Syria's possession of chemical weapons, signed the Chemical Weapons Convention (CWC) prohibiting further production and deployment of proscribed weapons, provided details to UN inspectors outlining the exact location of the regime's stockpiles and production facilities (a list validated by US intelligence records), and continues to comply with requirements stipulated in UN Security Council Resolution 2118, which demanded the full and complete dismantling of the regime's chemical weapons and related capabilities. ${ }^{6}$ In light of the strategic role chemical weapons played in the conflict up to that point, and the deterrent value Syrian officials assigned to these weapons in relation to their rivalry with Israel, a formal agreement to destroy these weapons constitutes an impressive foreign policy success and a clear victory for the credible application of coercive diplomacy. ${ }^{7}$ Threatening to fight worked and, as we will argue, reputations mattered. 


\section{The P-M-H Challenge}

One of the more significant problems with the advice offered by prominent critics of Obama's Syria strategy (that is, to back away from the coercive threats and ignore concerns about credibility) was their almost complete confidence in (and reliance on) the validity of the case evidence compiled by Press, Mercer and Hopf. To fully embrace the policy implications derived from these cases, one would have to believe that lessons from the early 1900s (Mercer and Press) or Cold War confrontations between two nuclear rivals (Press and Hopf) are perfectly suitable for providing definitive, policy-relevant advice in the context of an asymmetric conflict in 2013 involving the US and a smaller power over the use of chemical weapons. How realistic is that application? How sound is the basis for such policy prescriptions?

The combined implications of $\mathrm{P}-\mathrm{M}-\mathrm{H}$, if verified, are significant. As Weisiger and Yarhi-Milo point out: "From a policy perspective, the work of reputation critics suggests that leaders are tragically mistaken when they commit to the use of force in the expectation that doing so will yield long-term benefits beyond any gains in the immediate dispute" (2015: 476). If $\mathrm{P}-\mathrm{M}-\mathrm{H}$ is correct, in other words, leaders must seriously re-evaluate long-held beliefs about the importance of following through on commitments or the dangers of being called in repeated bluffs. If the P-M-H consensus is wrong, conversely, leaders could face disastrous consequences for abandoning such principles. In a world in which US deterrent and coercive capabilities undergird a significant measure of global security, the stakes are incredibly high.

How compelling, then, is the P-M-H challenge? As Dafoe and colleagues suggest: "There are a number of methodological and theoretical reasons why one should interpret [P-M-H] with caution" (2014: 385). To avoid repeating the many criticisms articulated elsewhere (see, for example, Copeland, 1997; Dafoe et al., 2014; Tingley and Walter, 2011; Tomz, 2011; Walter, 2006; Weisiger and Yarhi-Milo, 2015), there are two related problems we see as particularly relevant for our purposes. First, the reliance on a handful of cases from fundamentally different eras (with the attendant differences in "boundary conditions"; see Copeland, 1997) limits significantly the applicability of the P-M-H research to contemporary cases of asymmetric deterrence/compellence involving the US and smaller powers (and therefore its applicability to the Syria crisis). Second, the "theory" that P-M-H each claim to refute (that is, the basis upon which they dismiss the relevance of reputation) is ultimately a drastically simplified version of rational deterrence theory (RDT) that bears only superficial resemblance to the more sophisticated version of RDT we outline below (Dafoe and colleagues make a similar point when they discuss the 'misspecification of the null theory' in both Press and Mercer; 
see 2014: 388). The persuasiveness of the P-M-H challenge, ultimately, is contingent on the quality of the theory which is tested and found wanting; if this theory is one to which few actually subscribe, conclusions regarding the irrelevance of reputations are significantly undermined.

Daryl Press begins his book by specifying the theory he plans to debunk: "The conventional wisdom-which I call 'past actions' theoryholds that decision makers assess their enemies' credibility by evaluating their history for keeping (or breaking) commitments" (2007: 8). Instead, according to Press, the evidence compiled from his four case studies "suggests that the blood and wealth spent to maintain a country's record for keeping commitments are wasted: when push comes to shove, credibility is assessed on the basis of the current interests at stake and the balance of power, not on the basis of past sacrifices" (2007: 10; emphasis added). Press combines power and interests into current calculus (CC) theory, and this "new" theory, according to the author, decisively defeats past actions (PA) theory in empirical tests. But this forced distinction between $\mathrm{CC}$ and PA is based on an oversimplification of RDT that no serious scholar has put forward and no policy maker would ever endorse as a guide to action. We are not aware of any prominent deterrence theorist who has argued that past behaviour and related reputations are the only relevant determinants of credibility or that fighting for credibility is rational regardless of the balance of capabilities or interests in a given crisis.

Jonathan Mercer likewise offers a simplified version of RDT: "a state that yields should be viewed as irresolute and a state that stands firm should be viewed as resolute; however a state behaved in the last crisis should govern others' expectations of that state" (1996: 43). Mercer contends that this formulation "fits with the beliefs of deterrence theorists (and of decision makers) about how reputations form" (43). In other words, all that matters is how a state behaved in the last crisis. The same goes for Ted Hopf's operationalization of RDT, in which adversaries' assessments of credibility hinge entirely on the "lessons" they learn from previous conflicts (1994).

In sum, Press, Mercer and Hopf all assess the importance of reputation in international crises by testing a seriously deficient version of deterrence theory that takes as its core logic the complete interdependence of commitments. That they find little to no support for this "theory" should be expected and is, in fact, consistent with much prior work in the field. As Huth summarized in his assessment of empirical findings of studies of deterrence, "There is weak support for the strong-interdependence-of-commitments argument" (1997: 91). By way of alternative, P-M-H foreground power and interests (Press's CC theory is the most explicit articulation of this position). That is, they posit that leaders make a straightforward assessment of an adversary's capabilities and its willingness to use them in a particular crisis. These variables alone account for the credibility of a coercive threat. The problem with $\mathrm{P}-\mathrm{M}-\mathrm{H}$ is not, ultimately, its emphasis on power 
and interests; indeed, the work of Press, Mercer and Hopf is vital in reminding everyone (particularly policy makers) that fighting solely to maintain a reputation for resolve is foolish. ${ }^{8}$ Yet by artificially separating power and interests from reputations and past behaviour, $\mathrm{P}-\mathrm{M}-\mathrm{H}$ oversimplifies what is in fact a dynamic and interactive process; this more nuanced way of determining credibility is outlined below.

\section{The Rational Deterrence Theory Response}

Contrary to the P-M-H consensus that credibility is a function of only two core variables - power and interests - rational deterrence theorists have shown that the credibility of a coercive threat, measured in terms of its ultimate success or failure, is a function of a defender's capacity to satisfy four core prerequisites. ${ }^{9}$ Specifically, the standard, defender-oriented model of rational deterrence stipulates that a coercive retaliatory threat will be viewed by the adversary as credible if the defender: 1) clearly defines the behaviour deemed to be unacceptable (communication); 2) conveys a commitment to protect these interests; 3) possesses the capability to defend these commitments; and 4) demonstrates (in the current crisis and/ or in past, similar crises) the resolve or willingness to deny the objectives sought (deterrence by denial) or impose significant costs on adversaries who fail to comply (deterrence by punishment) (Harvey, 1998, 1999; see also Huth, 1997). If these prerequisites are satisfied, the expected net costs to the challenger should be greater than the expected net gains from non-compliance; thus, deterrence should work. The theory predicts failure if one or more of these conditions is absent. The relevant connection to reputations and past actions is found in the fourth prerequisite, resolve. ${ }^{10}$

Measuring resolve is inherently difficult. A common error in the coding process is treating a challenge-response sequence (in which the defender follows through on a retaliatory threat following a challenge) as a definitive case of deterrence failure, thereby ending the search for case evidence. In fact, deterrence successes are often achieved as a result of short-term failures; probes from a challenger provide an opportunity for defending states to clearly demonstrate resolve (along with capability), leading to deterrence success in the long term (Lieberman, 1995a). Evaluating deterrence in the context of protracted crises (and not as oneoff phenomena), therefore, provides a more accurate way to test core hypotheses regarding deterrence prerequisites and helps underscore the relevance of reputation for resolve that is otherwise lost in more simplified "single-play" assessments (for more on the sequential failure of deterrence over time and through stages, see George and Smoke, 1974).

Resolve can be demonstrated through costly signals, that is, "any action, statement, or condition that increases the political, economic, or 
military costs assigned to the status quo, while lowering the costs of responding to a challenger's probes" (Harvey, 1998: 186). Specific actions (such as deployment of air, naval or ground forces) or statements (public announcements of impending retaliation; explicit ultimatums and/or deadlines; congressional authorization to use military force; public displays of unity among coalition members in support of a response or threat) demonstrate and communicate commitment and resolve in the face of a potential challenge. ${ }^{11}$

In addition, however, adversaries are likely to look to earlier stages of a protracted crisis for information about how previous interactions and signalling played out in the past. Have signals translated into action following challenges/probes before? In other words, there is a dynamic interplay between signals (threats, commitments) and reputations (past behaviour), which together help establish resolve and, ultimately (in conjunction with capabilities and interests), credibility. This interplay is most prevalent in protracted crises (where lessons about past behaviour are obviously and more immediately relevant) but can also have an impact on broader deterrence outcomes across separate cases. While the specific reputation of a defender is crisis-based and situational, a general reputation can also be established that is dispositional and behavioural, and therefore more broadly applicable from one crisis to the next. ${ }^{12}$ Research by Mark Crescenzi, for example, shows that "states learn from the behavior of other nations, including the reputations states form through their actions in the international system" (2007: 382). Learning about US resolve and commitments from the country's behaviour in other, similar crises is often the best way for adversaries to obtain relevant information about US interests, its willingness to use military force and, more importantly, the costs it is willing to inflict on adversaries in retaliation for noncompliance. ${ }^{13}$

Downs and Jones, in their study of compliance with international treaties, similarly point out that "reputational inferences" are conditional, localized and segmented (2002: 109). The authors highlight the implication of this argument:

It follows that from the perspective of our model, the argument that a failure of NATO in an area like Kosovo or Macedonia will seriously erode NATO's credibility in connection with its commitments to Western Europe is wrong.... The states that do have to worry about these sorts of commitment failures are smaller states that believe they are valued the same as the states that were abandoned. (Downs and Jones, 2002: 110-11; emphasis added)

In other words, reputations are relevant but conditional and often based on assessments of similarities across cases. ${ }^{14} \mathrm{With}$ respect to the transferability 
of reputation between distinct crises, therefore, our version of RDT is necessarily conditional (that is, standing between complete interdependence and the $\mathrm{P}-\mathrm{M}-\mathrm{H}$ position of zero interdependence). Indeed, it is precisely this observation that guided our case selection: the Bosnia-Herzegovina, Kosovo and Iraq cases are similar enough along key dimensions to the Syria crisis to suggest the possibility to transfer lessons about US behaviour (or, from the US perspective, about the behaviour of small autocratic regimes) in protracted crises. ${ }^{15}$ Certainly, they are more relevant for understanding Syria than were the P-M-H cases, which did not bear even superficial similarity to almost any dimensions of that crisis.

The search for information about resolve, therefore, involves both specific and general reputation. As we demonstrate below, both factors were relevant to adversaries' assessments of US credibility in several recent crises. The important point, for now, is that there is no logical reason why adversaries would select only one or the other type of reputation, or rely entirely on a single dimension of resolve, when assessing the credibility of a retaliatory threat. States in international politics operate under conditions of imperfect information. As Tomz (2011) persuasively argued in his study of international finance, past behaviour and reputation can help mitigate these conditions; while an exact assessment of the interests and capabilities of an adversary is ideal, these types of calculations are impossible in reality (particularly as states actually have a rational incentive to misrepresent their willingness to use force; see Fearon, 1994b). Tomz develops a theory in which "the reputation of an actor [is] the impression others hold about its preferences and abilities" (2011: 10), an impression that is formed, in part, by Bayesian updating in which behaviour constitutes new "evidence" either to undermine or reinforce prior beliefs. US debtors and creditors turn to reputations and lessons from past actions to decipher intentions and to calculate the costs and benefits of specific actions. Reputations matter. There is no logical reason why the same patterns are not likely to play out in other contexts (something Tomz explicitly recognizes, see 2011: 237-40), especially when the costs (military force) are likely to be viewed by adversaries as even more significant, or when the issues are immediately relevant to regime survival.

In this sense, P-M-H models based on only two variables (power and interests) aren't so much wrong as they are incomplete. These models correctly identify the relevance of capability for credibility and successful coercion, but rational deterrence theory disaggregates credibility as a function of capability and signalling tied to communication, commitments (interests) and resolve (reputations). As Harvey explained elsewhere, "Since there is no logical reason to assign equal weights to the four prerequisites, unpacking communication, commitment and resolve facilitates more precise evaluations of the relevance and relative importance of these conditions as they change and interact in different contexts" (2006: 142). Again, this 
means that the four-variable model offers a better assessment of the very same factors (power and interest) stressed by the P-M-H consensus. Moreover, it provides clear and explicit theoretical justification for the inclusion of past actions and reputations as part of the definition of credibility. Far from the P-M-H perception that RDT posits reputation as definitive (the most extreme example is Press's PA theory), this version of RDT recognizes that reputations are only a part of the puzzle, potentially of greater or lesser importance depending on the specific circumstances of the coercive encounter in question. Any researcher who assumes that deterrence theorists are preoccupied exclusively with resolve or reputations is incorrect. In fact, the seven case studies included in Mercer and Press, which the authors (and their sponsors) claim provide conclusive evidence refuting claims that reputations (or past actions) are exclusively responsible for an adversary's perception of a defender's credibility, actually confirm what most deterrence theorists expect and have demonstrated in their research.

By combining interests, capabilities and resolve (that is, lessons learned about general and specific reputations that adversaries acquire from previous cases and past actions), RDT provides a stronger account of how reputations are connected to credibility, and the theory offers a much stronger explanation for the success and failure of coercive diplomacy in several recent asymmetric conflicts involving the US, including Syria 2013. In the next section we examine several of these crises, taking as our explicit focus the relevance of past behaviour and reputation over the course of multiple and protracted exchanges. ${ }^{16}$ As we will show, reputations are not completely irrelevant $(\mathrm{P}-\mathrm{M}-\mathrm{H})$, nor are they definitive to crisis outcomes (the weak version of deterrence tested and rejected by $\mathrm{P}-\mathrm{M}-\mathrm{H}$ scholars). Instead, the importance of reputations for any given case is best viewed along a continuum-sometimes more, sometimes less, depending on context and the presence/absence of other prerequisites. ${ }^{17}$

\section{Reputation Building in Protracted Crises: US Deterrence Encounters 1991-2003}

In this section, we examine three asymmetric crises involving the US and a smaller power over the past several decades: Bosnia-Herzegovina (19921995), Kosovo (1998-1999) and Iraq (1991-2003). Space constraints preclude exhaustive case discussion; for our purposes, however, it will be sufficient to focus on both general and specific reputation (as outlined above) and how each was relevant to the strategic calculations of US opponents in these cases. Obviously, the interaction of all four prerequisites is fundamental to the version of RDT outlined in the previous section; the 
case discussions reflect this by placing the influence of reputation and past behaviour in the context of evolving interests, commitments and capabilities (to consider it in isolation would be to commit the error P-M-H mistakenly ascribes to rational deterrence theory more broadly, that is, proposing reputation as definitive of credibility). Nonetheless, a more formal explication of the specific interactive effects (that is, the weighting of each prerequisite in any particular exchange) is beyond the scope of the present paper. We engage here in the preliminary tasks of establishing the relevance of reputations and past actions in recent US asymmetric encounters and tentatively sketching the nature of this influence in the context of the historical record, tasks that, if successful, combine to seriously undermine the claims of the P-M-H consensus, which would expect to find no such evidence.

\section{Bosnia-Herzegovina (1992-1995)}

Between 1992 and 1995, a series of coercive encounters between the US (supported by NATO and the UN) and Bosnian Serbs occurred in Bosnia-Herzegovina. As in Syria in 2013, these encounters involved a series of threats by the US and its allies to deter and/or compel a smaller power in the course of a violent and protracted conflict. The general pattern relating to coercive US action in Bosnia-Herzegovina is quite clear. Whenever US officials failed to respond to probes and challenges, violence escalated. When resolve was demonstrated through mobilizing military forces or airstrikes, escalation was controlled. If not buttressed by credible threats over time, adversaries continued to probe for weaknesses in resolve and commitments, and they began to contemplate the utility of challenging again. This pattern repeated itself in over a dozen separate exchanges in the two-year period, all of which provide evidence consistent with expectations derived from RDT (see Harvey, 1997). When conditions were met, deterrence succeeded. In the absence of one or more core prerequisites, deterrence failed. Reputations and resolve were central to these successes and failures.

The importance of maintaining (or re-establishing) a reputation for resolve is clearly illustrated by the events of late summer 1995. Just as peace prospects in the Balkans were improving, a mortar attack on the Markale market, in which 37 people were killed and another 80 or so injured, effectively derailed negotiations. Two days later, on August 30, NATO launched Operation Deliberate Force (ODF), a massive military manoeuvre (nearly 300 sorties) involving five countries (France, the Netherlands, Spain, the UK and the US) hitting Serb targets across Bosnia. Following the initial round of attacks, Western leaders were clear that airstrikes would continue until NATO demands were met. On September 1, a pause in ODF was announced and a new round of peace talks initiated (this time with the Bosnian Serbs negotiating as a 
single team). Even in the face of the massive NATO bombing campaign, however, Ratko Mladic was willing to accept only two of the three major NATO demands. Though he was prepared to stop shelling UN "safe areas" and to open routes into Sarajevo, he was not prepared (at that point) to pull heavy weapons from the outskirts of the city. As a result, NATO resumed airstrikes four days later, on September 5 and, along with the UN's Rapid Reaction Force, continued attacking Serb targets, making it clear to Mladic that only pulling the heavy weapons would end the bombardment. On September 14, nearly two weeks after it had initially begun, ODF was suspended as Serb leaders (including Mladic) finally agreed to withdraw their heavy weapons from the exclusion zone around Sarajevo. By September 21, some 250 heavy weapons had been removed and UN monitors were given unimpeded access to the area. The fighting had stopped, and the peace process was well underway.

The exchange can be seen as having two distinct stages. Stage one included the Markale attack and its immediate aftermath, as ODF was launched and UN/NATO demands (stop shelling UN "safe areas"; open routes into Sarajevo; remove heavy weapons from around the city) were articulated. With Mladic refusing to capitulate even in the face of a massive military campaign (ODF constituting, at the time, the largest military operation in NATO's history), this initial stage represents a clear failure of coercive diplomacy. The Bosnian Serbs were neither compelled to comply with, nor deterred from committing further infringements against, UN demands; after nearly four years of fighting, and numerous instances in which UN/NATO either backed down entirely ${ }^{18}$ or ended bombing campaigns prematurely, ${ }^{19}$ Mladic had real reason to doubt whether ODF would persist long enough or with enough force to achieve all of its demands. This reputation undermined the positive presence of the other prerequisites and caused Mladic to persist in the face of significant coercive pressure.

Stage two occurred when NATO resumed airstrikes on September 5, backed by artillery attacks from the Rapid Reaction Force and the launching of 13 Tomahawk cruise missiles from the USS Normandy stationed in the Adriatic Sea. In the face of this renewed coercive pressure, Mladic and the Bosnian Serbs capitulated to UN demands by withdrawing their heavy weapons from the 20-kilometre exclusion zone around Sarajevo. After nearly four years of bitter war, peace was finally within reach, with the subsequent signing of the Dayton Peace Accords widely acknowledged as a significant achievement of coercive diplomacy.

Success at stage two is intimately linked with initial failure at stage one. As has been argued, a short-term deterrence/compellence failure is often required to demonstrate (or re-establish) a reputation for resolve and is therefore necessary for long-term coercive success. How else would Mladic know that the alliance was committed to following through on their threats? Again, breaking a crisis down into extended threat/response 
sequences is important. Re-establishing resolve by re-commencing air and artillery strikes on September 5-though initially an apparent failure of deterrence/compellence - was necessary for the peace process that began on September 14 and the subsequent long-term deterrence success embodied by the Dayton Accords.

\section{Kosovo (1998-1999)}

In addition to specific, within-crisis credibility concerns, there is also evidence that general, dispositional reputations are transferable across crises. In Kosovo, Slobodan Milosevic based his decisions on assessments of the weakness in resolve that US and NATO officials had repeatedly demonstrated elsewhere (including, most immediately, in BosniaHerzegovina). As Steven Burg observed: "Milosevic's estimate of the probable potency of the NATO threat was likely to have taken into account the relatively limited air campaign conducted in Bosnia in 1995 and the similarly limited action taken by the United States and Britain against Iraq in December 1997" (2003: 93). Given the string of "frequent threats, failed ultimatums, and feeble deadlines that were immediately reset once passed," Daalder and O'Hanlon argue, it is not "surprising that Milosevic might have come to believe NATO would not strike or, when it did, that the allies would not be able to sustain the effort for long" (2000: 94-95). Milosevic made these feelings known in communications with Western officials. Sell recounts a conversation between Milosevic and Richard Holbrooke:

During a ceremonial dinner in late 1998, Holbrooke reminded Milosevic that he faced the prospect of massive bombing if he did not agree to the US proposal. And Milosevic, in an extraordinary scene, leaned back and replied, "Yes, Dick, I understand, but I'm sure that the bombing will be very polite." (2002: 303$)$

While it is important to recognize that such perceptions did not wholly determine Milosevic's decision to ignore the coercive threat (additional reasons may have been — and likely were — relevant, including the symbolic importance of Kosovo, domestic political pressures, Russian undermining of UN consensus, and so forth), it is nonetheless clear that past behaviour contributed to his calculation that airstrikes could be overcome and/or outlasted.

Of particular relevance in this regard was Milosevic's perception as to US/NATO casualty aversion. Milosevic assumed (and publically stated) that US leaders lacked the intestinal fortitude to sustain a bombing campaign. In comments to German Foreign Minister Joschka Fischer, Milosevic stated (in March 1999): "I can stand death—lots of it—but you 
can't" (quoted in Daalder and O'Hanlon, 2000: 94). During NATO's bombing campaign, Milosevic predicted: "You are not willing to sacrifice lives to achieve our surrender; but we are willing to die to defend our rights as an independent sovereign state" (quoted in Doder and Branson, 1999: 263). These perceptions were tied, again, to Milosevic's understanding of past crises (including Vietnam, Somalia, Haiti, Iraq and BosniaHerzegovina; for a general discussion of American casualty aversion with regard to these crises, see Gelpi et al., 2009). What Milosevic misunderstood, of course, was that NATO's sustained bombing campaign (and the alliance's crystal clear commitment to circumvent an uglier ground war) was designed precisely to avoid US/NATO military casualties, while limiting Kosovar and Serb civilian deaths, thus stripping from Milosevic's toolbox any counter-coercion leverage that would have come from exploiting the West's aversion to casualties (for a discussion of counter-coercion, see Byman and Waxman, 1999, 2002). When faced with mounting military failures, increasingly costly US/NATO attacks on high-value targets in Belgrade, and without any corresponding successes to point to, Milosevic was forced to capitulate.

\section{Iraq (1991-2003)}

With respect to deterrence exchanges between the US and Iraq, Janice Stein (1992) found that US deterrence efforts in the period leading up to the 1991 Gulf War failed for many of the same reasons; Saddam Hussein seriously underestimated American resolve to follow through with airstrikes, and miscalculated the impact of US air power on Iraq's ability to outlast coalition forces. But this was only the first of several specific deterrence crises between the US and Iraq from 1991 to 2003. Jon Alterman, for example, highlights the "iterative nature" of the confrontation, characterizing it as "repeated cycles of violence short of all-out war" (2003: 295). "Over time," Alterman writes, "Iraq learned how to deal successfully with the international community. It adopted policies of 'cheat and retreat,' testing limits and then quickly stepping back from the brink when punishment seemed imminent" (295).

Harvey and James similarly compiled evidence from six major exchanges during this period to test rational deterrence and compellence theory. "Dissecting the US-Iraq rivalry into its component parts," the authors point out, "reveals a series of separate (though interrelated) encounters that highlight the exact sequence within which appropriately designated deterrent/compellent threats, counter-coercive strategies and retaliatory responses unfold over time - failures at one stage can provide relevant information for interpreting and explaining successes later on" (2009: 222). Saddam Hussein's expectations in 2003, for example, were informed by US behaviour in similar deterrence cases in Bosnia-Herzegovina 
(1992-1995), Kosovo (1998-1999) and US attacks on Iraq in 1991 and 1998. Each of these interactions provided updated information regarding changes in US resolve and credibility.

The US decision to avoid moving into Baghdad in 1991-1992 confirmed Hussein's suspicions regarding Washington's general reputation for being casualty averse (for evidence of this perception, see Hussein's comments in Conflict Records Research Center, 1990: 16, and Conflict Records Research Center, 1991: 4). This reputation was reinforced by another significant deterrence encounter in 1998 (Operation Desert Fox), in which the Clinton administration launched a series of airstrikes, but no ground war, in retaliation for Hussein's refusal to comply with UN disarmament resolutions signed after the Gulf War. As Alterman explains:

Saddam Hussein apparently used his series of confrontations with Western coercive diplomacy as an educational opportunity. He was more difficult to coerce in 1998 than he was in 1991 because he understood well the limits of Western resolve and the ways to determine that resolve. (2003: 295)

Past experiences, in other words, reinforced Hussein's impressions of US resolve and led to perhaps the most serious underestimation of US credibility in the period leading up to the 2003 Iraq War (Harvey, 2012). Relying on Washington's general reputation for being casualty averse, and its more specific (crisis-based) reputation for relying exclusively on airstrikes in previous encounters, Hussein was convinced that US officials would use the same strategy in 2003: airstrikes but no invasion (as per 1998), and if an invasion, no push to Baghdad (as per 1991). ${ }^{20}$

\section{The Strategic Logic of US Deterrence Policy in Syria, 2011-2013}

The preceding analysis leads to several important conclusions that are directly relevant to assessing US foreign policy in the Syria case. Both general and specific (crisis-based) reputations for resolve played an important role in how US adversaries assessed the credibility of Washington's deterrent threats and, by extension, the success and failure of coercive diplomacy. As recent history demonstrated, weak (red-line) threats not only failed to control these crises but were often followed by an escalation in the violence, this time in the form of more significant chemical weapon attacks by the Syrian regime on civilian populations. Obama may have issued a red-line warning, but it was never clear to Syrian leaders whether he was committed to the deterrent threat or what the red-line actually meant, especially after repeated chemical attacks over the previous year produced no retaliatory response (see Dilanian and Cloud, 2013). In 
addition to the damage caused by a specific reputation for backing down in the face of these violations, the initial red-line threat was also undermined by a general US reputation for being casualty averse, a reputation compounded by the fatigue of a decade of war in Afghanistan and Iraq.

Much like past cases, as images of atrocities began to filter through broadcast and social media, political leaders, including the president, began to support a more explicit, coercive diplomatic approach to the crisis. The options were pretty straightforward; US officials could continue to simply ignore the attacks (the advice from many critics), but this would have been interpreted by Syrian officials as additional evidence of an absence of US resolve and further proof that the red-line threat was a bluff. This new benchmark for acceptable behaviour would almost certainly have resulted in additional chemical attacks. Alternatively, the administration could reinforce deterrence by issuing clearer statements supported by explicit plans to launch retaliatory strikes for non-compliance. The president selected the second strategy by issuing stronger threats (and demands) to re-establish US credibility, all backed by much clearer and increasingly more vocal commitments to impose costs on the Syrian regime. US Secretary of Defense Chuck Hagel was tasked with updating military plans for a Syria operation, and US Secretary of State John Kerry began the process of building the coalition-of-the-willing by engaging in talks with NATO allies, the United Arab Emirates, Saudi Arabia and Jordan.

Once these explicit threats (or costly signals) were issued, backing off, retreating or accepting the status quo became increasingly more difficult and less likely (for a discussion of costly signalling and audience costs, see Fearon, 1994a, 1997; for more recent treatments, see Levy, 2012; Trachtenberg, 2012). Anything approaching a significant retreat would almost certainly have been criticized by both sides in Congress (regardless of whether they endorsed authorization), and by the media and the American public, all pointing to disastrous consequences for American credibility. If Syrian officials did not fully appreciate the domestic pressures Obama was facing to follow through with some form of punitive airstrikes, Russian officials certainly did; they understood how the crisis was playing out, because they had faced the same escalation sequence (and dilemma) when trying to prevent airstrikes against Slobodan Milosevic. Russian officials no doubt conveyed this point to Assad when convincing him to accept the disarmament deal. ${ }^{21}$

In the end, both Bashar al-Assad and Vladimir Putin concluded that support from Russia and China in the UN Security Council would not be a sufficient guarantee against a US attack on Syria, and that there was no way to know for sure whether US officials would be able to limit the attacks to an "unbelievably small" campaign. Faced with US airstrikes, and no ability to impose significant counter-coercion costs on the US by 
exploiting the public's aversion to casualties (as Milosevic had learned in Kosovo), both Assad and Putin decided that the risks were too high. The threat worked.

It bears emphasizing that this outcome was not determined by shifting "interests" alone (that is, low initial US interest leading to failure, higher interests after the chemical attacks leading to success). In fact, as Press, Mercer, Walt, Zakaria and others persuasively argued in the aftermath of the chemical attacks and Obama's re-enforced coercive threats, the US had no real strategic interests in Syria (the humanitarian crisis notwithstanding); this was the reason these commentators argued that fighting for credibility made no sense and why they believed US officials should back down. Almost all of Obama's critics were making the same basic argument about low interests and limited capabilities to effect any significant change. All of the evidence points to an absence of plausible interests and commitments, and an unwillingness on the part of the administration, Congress and the public to support another military attack that risked drawing the US into another prolonged war. And yet deterrence and compellence succeeded. Why?

US coercive diplomacy succeeded because the threat was still credible (in the absence of clear US interests or a strong commitment to use significant power); and it was still credible because of US reputations and past actions from previous cases, including Bosnia-Herzegovina (1995), Kosovo (1999) and Iraq (2003) (as well as Libya 2011). With these cases in mind, it was virtually impossible for officials in Damascus and Moscow to know with any certainty whether US officials would limit the threatened air attacks to an "unbelievably small" campaign (Kosovo lasted 78 days; the Senate Foreign Relations Committee had granted Obama 90 days in the draft authorization resolution). ${ }^{22}$ Based on previous cases, Assad and Putin understood the risks: if airstrikes produced no clear signs of progress, if the regime retaliated by using chemical weapons again, or if humanitarian conditions on the ground continued to deteriorate (as in, for example, Kosovo), the pressure on Washington to sustain the bombing campaign would have been significant.

The mistake by Syrian officials was not in misreading US resolve, which was weak for most of the crisis. The regime's mistake was failing to control the violence that resulted from their efforts to probe for information about US commitments, resolve and credibility (for a discussion of the limited but escalating CW use prior to August 2013, see Dilanian and Cloud, 2013). They miscalculated the tipping point beyond which US officials would be compelled to re-enforce the credibility of their deterrent threat. In fact, each US deterrence crisis over the past two decades has had its respective tipping point. The Srebrenica massacre of 8,000 Bosnian Muslims in July 1995 led to a much stronger US intervention in the Bosnia-Herzegovina crisis and ultimately the signing of the Dayton 
Accords. The Kosovo air campaign was precipitated by the massacres of 45 Kosovar Albanians in Račak in January 1998. The tipping point pushing US officials over the line in Syria was the much larger chemical attacks in Ghouta in August 2013. Bashar al-Assad rationalized, with good reason, that US acquiescence to earlier chemical attacks was in part a function of the aversion to casualties compounded by a decade of war in Afghanistan and Iraq. He was right, but only to a point, namely, 1400 well-documented and highly visible casualties from sarin attacks.

Consistent with the cases of US deterrence failures discussed above, weak deterrent threats typically provoke probes by adversaries and, in the absence of any response, the administration obtains a crisis-based (or specific) reputation for being irresolute, which leads to an escalation in the violence and another tipping point. The August 2013 attacks provided the ammunition the administration needed to reinforce the deterrent threat and, as mentioned, once such explicit threats are issued, backing away becomes increasingly more difficult. The paradox of coercive diplomacy is that more credible threats are likely to succeed, but the stronger the threat, the higher the probability of military intervention if the adversary refuses to comply. Where P-M-H would have predicted failure (as made clear by those pushing the $\mathrm{P}-\mathrm{M}-\mathrm{H}$ evidence to denounce the administration's coercive strategy) there was instead success; US interests and capabilities were supplemented by and combined with sufficient resolve (as established by costly signals and past behaviour) to establish credibility. ${ }^{23}$

\section{Conclusion}

A decisive test between RDT and P-M-H does not require that we provide proof that past actions alone determine an adversary's behaviour or coercive outcomes; we have already provided several reasons why such a weak version of deterrence theory should be rejected. Our position is that interests, capabilities and reputations (both general and specific) combine to provide a better account of the perceptions, strategies, and successes and failures we explore across several recent US coercive encounters. Any and all evidence that reputations matter in facilitating an adversary's assessment of their opponent's credibility constitutes powerful disconfirmation of the P-M-H consensus that reputations are entirely independent, nontransferable and essentially irrelevant to US credibility. This paper therefore offers powerful evidence that complements recent quantitative work by Weisiger and Yarhi-Milo (2015) and builds upon earlier work that similarly pointed to the relevance of reputation (for example, Downs and Jones, 2002; Gibler, 2008; Guisinger and Smith, 2002; Harvey, 1997, 1998, 2006, 2012; Lieberman, 1995a, 1995b; Miller, 2012; Peterson, 2013 Sartori, 2005; Tingley and Walter, 2011; Tomz, 2011; Walter, 2006;). It 
should now be clear that reputations are relevant to an adversary's calculations of credibility. Of course, further unpacking the specific "formula" for this calculation in a particular case (that is, the interactive effects and/or weighting of each prerequisite) remains important moving forward (for early formal work in this direction, see Harvey 1998, 1999); absent a priori specification, it would be possible to explain any case after the fact by articulating different "recipes" for coercive success or failure. The purpose of this paper, however, was to return reputations to the menu, both theoretically, by articulating a more comprehensive version of RDT, and empirically, by exploring recent cases of American coercive diplomacy in asymmetric crises. Given the strength and profile of the P-M-H challenge, these were necessary and important tasks for the continued development of the deterrence literature.

What is striking about the policy debate over Syria in late summer 2013 is, ultimately, the extent to which the literature referenced above on the relevance of reputation was generally overlooked in favour of the evidence contained in P-M-H. A balanced review of the extant scholarship on credibility and reputations would have suggested that $\mathrm{P}-\mathrm{M}-\mathrm{H}$ research was not definitive enough to warrant its uncritical application to the Syria crisis. This point is particularly noteworthy in light of the fact that none of the significant disarmament outcomes achieved through UN Security Resolution 2118 would have occurred had the Obama administration accepted the critics' arguments or embraced the lessons extracted from the historical evidence they privileged. Moving forward, the US is certain to have additional asymmetric encounters with intransigent regimes (including, at some point, the regime of Bashar al-Assad), both in the Middle East and elsewhere. As the evidence in this paper indicates, the recognition that credibility is determined in part (but certainly not entirely) by past behaviour must remain a core component of US strategic logic. Fighting will enhance credibility in some, though not all, cases. Such is the complexity of coercive diplomacy, a fact which should be embraced rather than ignored in the course of foreign policy debates.

\section{Notes}

1 At the time of writing, hostilities between coalition forces (including Canada) and the Islamic State of Iraq and al-Sham (ISIS) dominate world headlines. The broader evolution of the Syria crisis is an important and fascinating subject, warranting research on the importance of credibility and reputations when confronting non-state actors or terrorist groups. This is not, however, our objective. The present article focuses specifically on the role of reputations in international politics; our goal is to extract important lessons about the theory and practice of coercive diplomacy in asymmetric crises involving the US and smaller powers from 1991 to 2013, with particular emphasis on the Syria case. 
2 For a complete review of the red-line threat and subsequent related statements, see Kessler (2013).

3 With respect to US-Iran relations, for example, the president had already issued a separate red-line warning in March 2013 (in an interview with Israel's Channel 2 News): "I have been crystal clear about my position on Iran possessing a nuclear weapon. That is a red line for us. It is not only something that would be dangerous for Israel. It would be dangerous for the world" (quoted in Carter, 2013).

4 Both Mercer and Press also published pieces in Foreign Affairs (Mercer, 2013) and Foreign Policy (Press and Lind, 2013) in an effort to apply their research and policy recommendations to the Syria case.

5 The full text of the authorization can be found at http://blogs.wsj.com/washwire/2013/ 09/03/full-text-senate-foreign-relations-committee-resolution-on-syria/

6 The final 8 per cent of Syria's declared stockpiles were handed over for destruction in June 2014 (Borger, 2014). For additional reports, updates and statistical analyses related to Syrian disarmament, see http://www.opcw.org/special-sections/syria/destructionstatistics/. Nonetheless, it is important to note that a fact-finding report released by the Organization for the Prohibition of Chemical Weapons (OPCW) in December of 2014 found compelling evidence that chlorine gas had been used as a chemical weapon in Syria. While the report did not assign blame, witnesses reported the use of helicopters, strongly indicating government involvement (the report can be found here: http://photos.state.gov/libraries/netherlands/328666/pdfs/THIRDREPORTOFTHE OPCWFACTFINDINGMISSIONINSYRIA.pdf). If true, the use of chlorine as a weapon is obviously troubling and challenges the success of the 2013 disarmament deal. Still, because chlorine has many industrial purposes, it is not considered a chemical weapon under the Chemical Weapons Convention (though its use as a chemical weapon is banned by international law) and was therefore not listed as part of the government's chemical weapons stockpiles to be dismantled. While using chlorine for hostile purposes violates in many ways the spirit of the 2013 disarmament deal, the possession of chlorine gas itself is not a violation, marking out somewhat of a grey area moving forward. Ultimately, the success of the initial deal cannot be entirely dismissed, even if future negotiations are required to address Syria's use of chemical agents not covered under the CWC.

7 Whether Assad's perceptions as to the utility of CW were accurate or not is beside the point. Repeated CW use by the Syrian regime over 2012-2013 suggests that military leaders believed they served some strategic or psychological purposes, a belief that would have made them reluctant, all else being equal, to give them up. Recent reports of chlorine gas being used as a weapon (see note 6 above) further underscore the value the regime seems to place on $\mathrm{CW}$ as a strategic asset.

8 While largely absent in scholarly work on deterrence, this "complete-interdependenceof-commitments" position does find voice in policy commentary. See, for example, Slaughter (2014).

9 One of the central debates in the study of deterrence is that between rational choice theorists (for example, Huth, Russett, Fearon) and political psychologists (for example, Lebow, Stein, Jervis); the present article argues from a rational choice perspective, but does not (indeed cannot, given space constraints) engage this debate in full nor justify every assumption of the rational choice framework. Instead, we narrow our focus to the fourth prerequisite of established rational deterrence theory - resolve - and, even further, to the influence of past actions and reputations in establishing and communicating resolve (which, in conjunction with the other three prerequisites, determines the credibility of a deterrent threat). The specificity of this task is a reflection of the maturity and complexity of the deterrence literature; moreover, it constitutes an important contribution to that literature, particularly in the context of recent contributions that dismiss 
the relevance of reputation (from both a rational choice [Press] and political psychology [Mercer] perspective), but also because, as Huth pointed out in 1997: "Reputation is the least developed component of deterrence theory" (97), an observation that largely holds today (see, for example, the discussion in Weisiger and Yarhi-Milo, 2015).

10 An interesting component of the study of reputation is deciphering the question of, as Huth (1997) put it, "reputation for whom?" That is, does reputation adhere to the state, the political system (for example, democratic institutions) or to a specific individual leader? While the evidence in this paper suggests reputational inferences can be (and are) made vis à vis all three units of analysis, we defer making theoretical or analytical statements regarding these distinctions; in this sense, we generally agree with Huth's assessment that "reputations for resolve could be plausibly associated with either [individual or state] unit of analysis" (1997: 78). Determining to whom (or at what level) US adversaries assign reputation (state, democratic institution, or specific leader) is a fascinating subject, but ultimately beyond the scope of this paper. Our intent is to establish the broad relevance of reputation (wherever assigned) in US asymmetric encounters over the last several decades.

11 In this regard, we consider both "tying hands" and "sunk costs" as costly signals (see Fearon, 1997). While each operates according to a slightly different logic, for practical purposes, "there are few examples of [a] pure case" of each; as Fearon explains: "Building arms or mobilizing troops entails costs no matter what the outcome, but they also may affect the state's expected value for fighting versus acquiescing in a challenge (which may have something like a tying-hands effect)" (1997: 70). Both types, therefore, ultimately help to signal resolve.

12 Readers will note the similarity in terminology with Huth's well-known distinctions between general and immediate deterrence more broadly: "Deterrent threats may be issued in response to a pressing short-term threat of attack (immediate deterrence) or a deterrent policy may seek to prevent such short-term crises and militarized conflicts from arising (general deterrence)" (1999: 27). Indeed, the distinction between general and immediate deterrence is a useful anchor for discussing general and specific/immediate reputations, or general and immediate versions of communication, commitments/ interests and capabilities. General reputations form across cases and can lead to general or immediate deterrence success or failure, depending on the presence or absence of other prerequisites. Immediate (specific) reputations form in the context of an immediate deterrence encounter. Immediate deterrence encounters follow general deterrence failures, and the success or failure of immediate deterrence encounters depends on the presence and absence of key conditions over time in protracted crises. Immediate deterrence encounters (successes or failures) can have an impact across cases by influencing adversaries' perceptions of general reputation. We can also locate slightly different indicators when isolating core prerequisites for general and immediate versions of deterrence. For example, general "capabilities" include the power and capabilities of the US (including nuclear power and second-strike capability to deter nuclear attack). Immediate capabilities include regional military balances and crisis-based deployments of, for example, air power.

13 A strong general reputation for resolve could even, hypothetically, prevent general deterrence failure with respect to a third party, though this possibility is notoriously difficult to engage empirically because it constitutes a non-event (that is, no crisis arises). The authors thank an anonymous reviewer for this point.

14 Indeed, these assessments (or perceptions) themselves are conditional, not determinate. That is, reputations are "in the eye of the beholder," and are therefore variable and unpredictable (but not entirely random). This unpredictably renders it difficult for an actor to "send" precise signals about its resolve through its behaviour (or, rather, to expect that these signals will always be correctly received). The logical implication of this fact is 
not, as P-M-H argues, that reputations cannot form; indeed, it establishes the exact opposite; if reputation is in the eye of the beholder, it is impossible to say for certain whether specific behaviour will always or never result in a particular perception on the part of the adversary. While obviously rendering precise prediction difficult, this logic is far more compatible with our conditional version of RDT than it is with the P-M-H position that reputations are never relevant.

15 The point is not that cases need be identical in order for reputations to transfer or for states to infer lessons from one crisis to the next; quite obviously, no two cases can ever be identical (even those between the same adversaries over the same stakes). Yet the cases examined in this paper are similar enough to reasonably conclude that such transfer could occur (recall, again, that reputations remain in the "eye of the beholder"; see endnote 14, above). They involved protracted military confrontations between the US and a smaller authoritarian (or at the very least, highly centralized) adversary over non-vital American interests, and all occurred in a relatively truncated (approximately 20 -year) time frame. Moreover, our explanation of the outcomes in these cases, which highlights the importance of lessons adversaries pick up from similar cases, is demonstrably superior to P-M-H accounts that rely exclusively on power and interests alone. When gauging the credibility of a US threat, adversaries are preoccupied with determining Washington's "willingness" to deploy and use its capabilities - that is, Washington's "actual" power and related motivation to impose costs is far more relevant than "potential" US power or the country's aggregate capabilities. Reputations and past actions in similar cases, in other words, help adversaries decipher the right kind of power (capabilities) when measuring US credibility.

16 A protracted crisis approach is ideally suited to extracting theoretically relevant data points throughout a crisis; because international crises unfold over time, it is reasonable to assume that the logic of (immediate) deterrence applies across multiple exchanges; of course, identifying distinct "exchanges" still requires the judgment of the scholar familiar with the available historical record to decide when they "began" and "ended," so that they may be evaluated with respect to deterrence success or failure. Nonetheless, this approach remains significantly more fine-grained, from a historical point of view, than simply waiting until the end of a crisis to make a one-off determination of success or failure (and the attendant relevance of resolve, or any other of the RDT prerequisites).

17 For a more formal treatment of the interactive effects of the four prerequisites in the context of multiple exchanges in protracted conflicts, see Harvey's Boolean analysis (1998) of three prominent deterrence data sets.

18 As in July 1995 in Srebrenica (see Cohen, 1995c).

19 As occurred in May 1995 (see Cohen, 1995a, 1995b; Whitney, 1995).

20 To illustrate the point, consider the following conclusions by George Piro, the FBI agent responsible for interrogating Hussein following his capture in December 2003: "[Saddam Hussein] thought the United States would retaliate with the same type of attack as we did in 1998 under Operation Desert Fox.... He survived that once. [Thus,] he was willing to accept that type of attack. That type of damage" (Pelley, 2008).

21 The Russian role in the Syria crisis is generally acknowledged, though documentary evidence of Moscow's influence over Damascus is scant, given both the contemporary nature of the crisis and the closed political systems of Russia and Syria. Nonetheless, Russian Foreign Minister Sergey Lavrov's remarks at a joint press conference with Secretary Kerry on September 14, 2014, announcing the framework to eliminate Syrian CW, clearly indicate the Russian role in brokering the deal. See US Department of State (September 14, 2013) "Remarks with Russian Foreign Minister Sergey Lavrov after Their Meeting," http://www.state.gov/secretary/remarks/2013/09/ 214250.htm. 
22 Peter Feaver (2013) offers the opposite interpretation, suggesting that Assad and Putin struck the deal precisely because Obama's threat was not credible: "Putin and Assad acted not because they feared the imminent strike. They acted at the moment when they least had to fear the strike in order to get the most from Obama." We do not find this interpretation persuasive for multiple reasons. First, as Daniel Drezner (2013) pointed out, the deal was hardly a master stroke of diplomacy for Assad or Putin; Syria (a key ally of Moscow) was significantly weakened by the deal. Second, the logical implication of Feaver's interpretation is that Assad and Putin preferred the disarmament outcome to one in which they (a) retain their chemical weapons (as a modest deterrent against Israel and a useful weapon against the opposition), (b) force Obama to admit he was bluffing (as Feaver implies he was) thereby seriously damaging the president's credibility at home and undermining his relations with key allies (including Israel), (c) deliver a serious blow to the Syrian opposition, and (d) emerge from the crisis with their respective positions in the region not only intact but buttressed by the fact that they stood up to the US. This alternative scenario would have served Assad's interests far more than the humiliation he suffered from having to acknowledge the existence of, and then systematically dismantle, his chemical weapons. To argue that the scenario outlined above is somehow less appealing to Assad than the disarmament deal is, in a word, puzzling.

23 It is important to note that interests, capabilities, commitments and resolve are not always or necessarily additive. It is conceivable that, in some cases, capabilities could have a negative interaction with reputations; the ability to apply overwhelming force at low costs can make a threat credible in the absence of resolve. On the other hand, there are cases in which the threat of overwhelming force would not compensate for the absence of resolve or interests, and could undermine credibility and deterrence efforts. In the Kosovo case, for example, the US/NATO airstrike strategy, combined with an explicit refusal to mobilize more capabilities by launching a ground war, was the ideal strategy to maximize credibility without jeopardizing alliance support and solidarity. Any additional application of military force in the form of a ground war would have increased the number of military and civilian casualties, undermined alliance unity, jeopardized public support for the intervention and provided Milosevic with strong counter-coercion leverage to exploit the alliance's aversion to casualties (see Harvey, 2006). Interaction effects are not necessarily additive, and credibility (deterrence success) often depends on the right mix of strategies. These possibilities do not, of course, obviate the relevance of reputation (or any other prerequisite), but simply reinforce the scholar's imperative to carefully unpack the logic and evidence of any particular case.

\section{References}

Alterman, Jon. 2003. “Coercive diplomacy against Iraq, 1990-98." In The United States and Coercive Diplomacy, ed. Robert Art and Patrick Cronin. Washington: United States Institute of Peace.

Biddle, Stephen. 2013. "Congressional Testimony: Assessing the Case for Striking Syria." Council on Foreign Relations, September 10. http://www.cfr.org/syria/assessing-casestriking-syria/p31373 (August 21, 2014).

Borger, Julian. 2014. "Syria hands over final chemical weapons for destruction." The Guardian, June 23. http://www.theguardian.com/world/2014/jun/23/syria-chemicalweapons-final-destruction-un-deadline (March 16, 2015). 
Burg, Steven. 2003. "Coercive Diplomacy in the Balkans: The US Use of Force in Bosnia and Kosovo." In The United States and Coercive Diplomacy, ed. Robert Art and Patrick Cronin. Washington: United States Institute of Peace.

Byman, Daniel and Matthew Waxman. 1999. "Defeating US coercion." Survival: Global Politics and Strategy 41 (2): 107-20.

Byman, Daniel and Matthew Waxman. 2002. The Dynamics of Coercion: American Foreign Policy and the Limits of Military Might. New York: Cambridge University Press.

Carter, Chelsea J. 2013. "Obama: Iran more than a year away from developing nuclear weapon." CNN, March 15. http://www.cnn.com/2013/03/14/world/meast/israel-obamairan/ (August 22, 2014).

Cohen, Roger. 1995a. "NATO May Be Called On to Silence Guns in Sarajevo." New York Times, May 25, A14.

Cohen, Roger. 1995b. "Serbs Call and Raise: NATO's Air Strikes Hike the Stakes in Bosnia for All Sides in the Conflict." New York Times, May 27, 4.

Cohen, Roger. 1995c. "The World: Withdrawal Symptoms; Honor, Too, Is Put to Flight in Bosnia." New York Times, July 16, E1.

Conflict Records Research Center. 1990. "Saddam Hussein and the Revolutionary Command Council Discussing the Iraqi Invasion of Kuwait and the Expected US Attack." CRRC \#SH-SHTP-A-001-042, December 29, Washington DC. http://crrc.dodlive.mil/files/ 2013/06/SH-SHTP-A-001-042.pdf.

Conflict Records Research Center. 1991. "Saddam Hussein Meeting with Advisors Regarding the American Ground Attack During First Gulf War, Garnering Arab and Iraqi Support, and a Letter to Gorbachev." CRRC \#SH-SHTP-A-000-931, February 24, Washington DC. http://crrc.dodlive.mil/files/2013/01/SH-SHTP-A-000-931_TF.pdf.

Copeland, Dale. 1997. "Do reputations matter?" Security Studies 7 (1): 33-71.

Crescenzi, Mark. 2007. "Reputation and Interstate Conflict." American Journal of Political Science 51 (2): 382-96.

Daalder, Ivo H. and Michael E. O'Hanlon. 2000. Winning Ugly: NATO's War to Save Kosovo. Washington DC: Brookings Institution Press.

Dafoe, Allan, Jonathan Renshon and Paul Huth. 2014. "Reputation and Status as Motives for War." Annual Review of Political Science 17: 371-93.

Dilanian, Ken and David S. Cloud. 2013. "US saw yearlong rise in chemical weapons use by Syria.” Los Angeles Times, September 6. http://www.latimes.com/world/middleeast/lafg-syria-intel-20130907,0,2289261.story\#ixzz2mKOqBKH5 (May 20, 2014).

Doder, Dusko and Louise Branson. 1999. Milošević: Portrait of a Tyrant. New York: The Free Press.

Downs, George W. and Michael A. Jones. 2002. "Reputation, Compliance, and International Law." Journal of Legal Studies 31 (1): 95-114.

Drezner, Daniel. 2013a. "Swing and a miss: The Sabermetric spat about whether it's important for a president to appear "credible." Foreign Policy September 16. http://foreign policy.com/2013/09/16/swing-and-a-miss/ (August 25, 2014).

Drezner, Daniel. 2013b. "Syria, Iran, and the Credibility Fairy." Foreign Policy September 19. http://foreignpolicy.com/2013/09/19/syria-iran-and-the-credibility-fairy/ (August 27, 2014).

Fallows, James. 2013. "Syria: Some Arguments for Intervention, and a Response." The Atlantic, August 31. http://www.theatlantic.com/international/archive/2013/08/syriasome-arguments-for-intervention-and-a-response/279241 (August 22, 2014).

Fearon, James. 1994a. "Signaling versus the Balance of Power and Interests: An Empirical Test of a Crisis Bargaining Model." Journal of Conflict Resolution 38 (2): 236-69.

Fearon, James. 1994b. "Rationalist explanations for war." International Organization 49 (3): 379-414.

Fearon, James. 1997. "Signaling Foreign Policy Interests: Tying Hands versus Sinking Costs." Journal of Conflict Resolution 41 (1): 68-90. 
Feaver, Peter. 2013. “A 'Credible' Threat Likely Did Not Catalyze the Russian-Syrian Gambit." Foreign Policy September 11, http://foreignpolicy.com/2013/09/11/a-crediblethreat-likely-did-not-catalyze-the-russian-syrian-gambit/ (September 19, 2015).

Friedersdorf, Conor. 2013. "Presidents Shouldn't Be Able to Credibly Threaten Wars That the People Oppose." The Atlantic, September 6. http://www.theatlantic.com/politics/ archive/2013/09/presidents-shouldnt-be-able-to-credibly-threaten-wars-that-the-peopleoppose/279410/ (August 22, 2014).

Gelpi, Christopher, Peter D. Feaver and Jason Reifler. 2009. Paying the Human Costs of War: American Public Opinion and Casualties in Military Conflicts. Princeton: Princeton University Press.

George, Alexander and Richard Smoke. 1974. Deterrence in American Foreign Policy: Theory and Practice. New York: Columbia University Press.

Gibler, Douglas. 2008. "The Costs of Reneging: Reputation and Alliance Formation." Journal of Conflict Resolution 52 (3): 426-54.

Guisinger, Alexandra and Alastair Smith. 2002. "Honest Threats: The Interaction of Reputation and Political Institutions in International Crises." Journal of Conflict Resolution 46 (2): 175-200.

Harvey, Frank P. 1997. "Deterrence and ethnic conflict: The case of Bosnia-Herzegovina, 1993-94." Security Studies 6 (3): 180-210.

Harvey, Frank P. 1998. "Rigor Mortis or Rigor, More Tests: Necessity, Sufficiency, and Deterrence Logic.” International Studies Quarterly 42 (4): 675-707.

Harvey, Frank P. 1999. "Practicing Coercion: Revisiting Successes and Failures Using Boolean Logic and Comparative Methods." Journal of Conflict Resolution 43 (6): 840-71.

Harvey, Frank P. 2006. "Getting NATO's Success in Kosovo Right: The Theory and Logic of Counter-Coercion." Conflict Management and Peace Science 23 (2): 139-58.

Harvey, Frank P. 2012. Explaining the Iraq War: Counterfactual Theory, Logic and Evidence. New York: Cambridge University Press.

Harvey, Frank P. and Patrick James. 2009. "Deterrence and Compellence in Iraq, 1991-2003: Lessons for a Complex Paradigm." In Complex Deterrence: Strategy in the Global Age, ed. T.V. Paul, Patrick M. Morgan and James J. Wirtz. Chicago: University of Chicago Press.

Hopf, Ted. 1994. Peripheral Visions: Deterrence Theory and American Foreign Policy in the Third World, 1965-1990. Ann Arbor: University of Michigan Press.

Huth, Paul. 1997. "Reputations and deterrence: A theoretical and empirical assessment." Security Studies 7 (1): 72-99.

Huth, Paul. 1999. "Deterrence and International Conflict." Annual Review of Political Science 2: 25-48.

Kessler, Glenn. 2013. "President Obama and the 'red line' on Syria's chemical weapons." Washington Post, September 6. http://www.washingtonpost.com/blogs/fact-checker/ wp/2013/09/06/president-obama-and-the-redline-on-syrias-chemical-weapons/ (March $30,2015)$.

Klein, Ezra. 2013. "Why Obama shouldn’t care about backing down in Syria.” Washington Post, September 12. http://www.washingtonpost.com/blogs/wonkblog/wp/2013/09/12/ why-obama-shouldnt-care-about-backing-down-on-syria (August 23, 2014).

Larison, Daniel. 2013. "The desperation of the Syria hawks' 'credibility' argument." The American Conservative, May 6. http://www.theamericanconservative.com/larison/thedesperation-of-the-syria-hawks-credibility-argument (August 22, 2014).

Levy, Jack S. 2012. "Coercive Threats, Audience Costs, and Case Studies." Security Studies 21 (3): 383-90.

Lieberman, Elli. 1995a. Deterrence Theory: Success or Failure in Arab-Israeli Wars? McNair Paper 45. Washington DC: National Defense University. 
Lieberman, Elli. 1995b. "What Makes Deterrence Work? Lessons from the Egyptian-Israeli Rivalry." Security Studies 4 (4): 851-910.

Manzi, Jim. 2013. "A dissent on Syria." National Review, September 5. http://www.national review.com/corner/357680/dissent-syria-jim-manzi (August 23, 2014).

Mercer, Jonathan. 1996. Reputation and International Politics. Ithaca NY: Cornell University Press.

Mercer, Jonathan. 2013. "Bad Reputation: The Folly of Going to War for "Credibility." Foreign Affairs August 28. http://www.foreignaffairs.com/articles/136577/jonathanmercer/bad-reputation (August 22, 2014).

Miller, Gregory D. 2012. The Shadow of the Past: Reputation and Military Alliances before the First World War. Ithaca NY: Cornell University Press.

Mohammed, Arshad and Andrew Osborn. 2013. "Kerry: Syrian surrender of chemical arms could stop U.S. attack," Reuters, September 9. http://www.reuters.com/article/2013/09/ 09/us-syria-crisis-kerry-idUSBRE9880BV20130909 (September 22, 2015).

Office of the Press Secretary. 2012. "Remarks by the President to the White House Press Corps." The White House, August 20. https://www.whitehouse.gov/the-press-office/ 2012/08/20/remarks-president-white-house-press-corps (June 18, 2014).

Pelley, Scott. 2008. "Interrogator Shares Saddam's Confessions." 60 Minutes Online, January 27. http://www.cbsnews.com/stories/2008/01/24/60minutes/main3749494.shtml (March 22, 2015).

Peterson, Timothy M. 2013. "Sending a Message: The Reputation Effect of US Sanction Threat Behavior." International Studies Quarterly 57 (4): 672-82.

Press, Daryl. 2007 [2005]. Calculating Credibility: How Leaders Assess Military Threats. Ithaca NY: Cornell University Press.

Press, Daryl and Jennifer Lind. 2013. "Red lines and red herrings." Foreign Policy May 6. http://walt.foreignpolicy.com/posts/2013/05/06/red_lines_and_red_herrings (August 21, 2014).

PressTV. 2013. "Pentagon extends deployment of US warships near Syria." PressTV, September 13. http://www.presstv.com/detail/2013/09/13/323672/us-warships-to-remainin-mediterranean/ (August 24, 2014).

Sartori, Anne E. 2005. Deterrence by Diplomacy. Princeton NJ: Princeton University Press.

Sell, Louis. 2002. Slobodan Milosevic and the Destruction of Yugoslavia. Durham NC: Duke University Press.

Slater, Jerome. 2013. "Syria, Credibility, and 'Armchair Isolationism."' Foreign Policy September 5. http://walt.foreignpolicy.com/posts/2013/09/05/syria_credibility_and_ armchair_isolationism (August 24, 2014).

Slaughter, Anne-Marie. 2014. "Stopping Russia Starts in Syria." Project Syndicate, April 23. http://www.project-syndicate.org/commentary/anne-marie-slaughter-on-how-usintervention-in-the-syrian-civil-war-would-alter-vladimir-putin-s-calculus-in-ukraine (August 8, 2014).

Stein, Janice G. 1992. "Deterrence and Compellence in the Gulf, 1990-91: A Failed or Impossible Task?" International Security 17 (2): 147-79.

Tingley, Dustin and Barbara Walter. 2011. "The Effect of Repeated Play on Reputation Building: An Experimental Approach.” International Organization 65 (2): 343-65.

Tomz, Michael. 2011. Reputation and International Cooperation: Sovereign Debt across Three Centuries. Princeton NJ: Princeton University Press.

Trachtenberg, Mark. 2012. Audience Costs: An Historical Analysis." Security Studies 21 (3): 3-42.

United States Department of State. 2013. "Remarks with Russian Foreign Minister Sergey Lavrov After Their Meeting." September 14. http://www.state.gov/secretary/remarks/ 2013/09/214250.htm (July 11, 2015). 
Walt, Stephen. 2013. "We're Going to War Because We Just Can't Stop Ourselves." Foreign Policy, May 27. http://foreignpolicy.com/2013/08/27/were-going-to-war-because-wejust-cant-stop-ourselves/ (August 22, 2014).

Walter, Barbara. 2006. "Building Reputation: Why Governments Fight Some Separatists but Not Others." American Journal of Political Science 50 (2): 313-30.

Weisiger, Alex and Keren Yarhi-Milo. 2015. "Revisiting Reputation: How Past Actions Matter in International Politics." International Organization 69 (2): 473-95.

Whitney, Craig R. 1995. "Diplomatic moves pressed by Paris." New York Times, May 28, 1.

Zakaria, Fareed. 2013. "US credibility is not on the line in Syria." Washington Post, May 8. http://articles.washingtonpost.com/2013-05-08/opinions/39115046_1_u-s-marinesyria-cold-war (August 23, 2014). 